\title{
Pengaruh Motivasi Belajar dan Kompetensi Berbasis E-Learning di Masa Pendemi Covid-19
}

\author{
Yanita Ella Nilla Chandra ${ }^{1 凶}$, Syamsurizal $^{2}$, Rizka Sakinah $^{3}$ \\ Politeknik Negeri Jakarta, Indonesia ${ }^{1,2,3}$ \\ e-mail: yanitaella.nillachandra@bisnis.pnj.ac.id
}

\begin{abstract}
This study aims to identify learning motivation and competency development based on edevelopment through e-learning for students to meet the needs of the work industry. This research uses a quantitative approach with explanatory research methods. The Department of Business Administration, State Polytechnic of Jakarta conducted this research. In this research, the population was 1,094 students of the Department of Business Administration. State Polytechnic of Jakarta. The sample used in this study was 100 taken by random sampling. The data collected in this study used a closed questionnaire with a Likert scale of 5. The data analysis carried out in this study was a multiple linear regression analysis. The research results explain that learning motivation influences the competence of lecturers and e-learning methods given to students. The research results also clarify that the competencies possessed in the online learning on the e-learning have a positive and significant effect through the e-learning method taught by lecturers.
\end{abstract}

Keywords: motivation, competencies, e-learning

\begin{abstract}
Abstrak
Penelitian ini bertujuan mengidentifikasi motivasi belajar dan pengembangan kompetensi berbasis $e$-development yaitu e-learning pada mahasiswa untuk memenuhi kebutuhan industri kerja. Rancangan penelitian menggunakan pendekatan kuantitatif dengan metode explanatory research. Penelitian ini dilaksanakan di Jurusan Administrasi Bisnis, Politeknik Negeri Jakarta. Populasi pada penelitian ini adalah mahasiswa Jurusan Administrasi Bisnis Politeknik Negeri Jakarta sebanyak 1.094 mahasiswa dengan sampel dalam penelitian ini sebesar 100 diambil secara acak. Teknik pengumpulan data pada penelitian ini menggunakan kuesioner yang bersifat tertutup dengan skala Likert skala 5. Analisis data yang dilakukan dalam penelitian menggunakan analisis regresi linier berganda. Hasil penelitian menjelaskan bahwa motivasi belajar berpengaruh terhadap kompetensi dosen dan metode $e$-learning yang diberikan kepada mahasiswa. Hasil penelitian juga menjelaskan bahwa kompetensi yang dimiliki dosen dalam proses belajar secara daring berpengaruh positif dan signifikan terhadap metode e-learning yang diajarkan.
\end{abstract}

Kata kunci: motivasi, kompetensi, e-learning 


\section{PENDAHULUAN}

Wabah corona virus disease 2019 (Covid19) telah melanda 215 negara di dunia sehingga memberikan tantangan bagi lembaga pendidikan, khususnya perguruan tinggi. Pemerintah menciptakan peraturan seperti pelarangan membuat kerumunan, pelaksanaan pembatasan sosial (social distancing), penerapan protokol kesehatan, dan selalu mencuci tangan pakai sabun sebagai langkah mitigasi penyebaran Covid-19. Melalui Surat Edaran Kemendikbud Dikti No. 1 tahun 2020, Kementerian Pendidikan dan Kebudayaan Indonesia, melarang perguruan tinggi untuk melaksanakan perkuliahan tatap muka dan memerintahkan penyelenggaraan perkuliahan atau pembelajaran secara daring. Hal ini menuntut perguruan tinggi untuk dapat menyelenggarakan pembelajaran secara daring atau online (Firman \& Rahayu, 2020).

Menurut Moore dkk. (2011) pembelajaran daring merupakan pembelajaran yang menggunakan jaringan internet dengan aksesibilitas, konektivitas, fleksibilitas, dan kemampuan untuk memunculkan berbagai jenis interaksi pembelajaran. Penelitian yang dilakukan oleh Zhang dkk. (2004) menunjukkan bahwa penggunaan internet dan teknologi multimedia mampu merombak cara penyampaian pengetahuan dan dapat menjadi alternatif pembelajaran yang dilaksanakan dalam kelas tradisional.

Pada tataran pelaksanaannya, pembelajaran daring memerlukan dukungan perangkat-perangkat mobile seperti smartphone, laptop, tablet, dan komputer yang dapat dipergunakan untuk mengakses informasi kapan saja dan di mana saja (Gikas \& Grant, 2013). Pembelajaran secara daring telah menjadi tuntutan dunia pendidikan sejak beberapa tahun terakhir untuk tetap menunjang kebutuhan mahasiswa dalam melakukan pembelajaran secara baik dan efektif di masa pandemi. Perguruan tinggi saat ini menggunakan pembelajaran online yaitu $e$ learning. e-learning merupakan salah satu media pembelajaran yang sudah mulai digunakan dalam dunia pendidikan di masa covid-19 saat ini yaitu media pembelajaran berbasis komputer dan internet.

Menurut Rosenberg (2001), Elearning merupakan pemanfaatan teknologi internet untuk mendistribusikan materi pembelajaran sehingga peserta didik dapat mengakses dari mana saja. Dalam penelitian yang dilakukan oleh Suwastika (2018) salah satu faktor yang memengaruhi pembelajaran online menggunakan $e$ learning yaitu motivasi belajar mahasiswa dan kompetensi dosen yang mengikuti perkuliahan.

Menurut Sardiman (2018) motivasi belajar adalah keseluruhan daya penggerak di dalam diri siswa yang menimbulkan kegiatan belajar, yang menjamin kelangsungan dari kegiatan belajar dan memberikan arah pada kegiatan belajar, sehingga tujuan yang dikehendaki oleh subjek belajar itu dapat tercapai. Maka dari itu, motivasi belajar menjadi keseluruhan daya penggerak yang terletak di dalam diri peserta didik yang memunculkan niat untuk mengikuti perkuliahan menggunakan $e$ learning.

Beberapa penelitian telah dilakukan untuk menjelaskan hubungan dan pengaruh motivasi belajar terhadap e-learning. Hasan \& Bao (2020) menjelaskan bahwa motivasi sebagai niat mahasiswa untuk mengikuti perkuliahan secara daring mampu mempengaruhi pembelajaran secara daring menggunakan e-learning. Hasil penelitian tersebut juga menjelaskan bahwa motivasi berpengaruh terhadap kompetensi yang dimiliki seorang dosen. Hasil penelitian Satria \& Kuswara (2013) menjelaskan bahwa motivasi belajar sebagai niat mahasiswa untuk mengikuti perkuliahan didukung oleh kompetensi dosen yang memberikan pengajaran. Makin baik kompetensi yang dimiliki dosen dalam memberikan model pembelajaran, semakin mendukung motivasi mahasiswa untuk mengikuti perkuliahan. Motivasi mampu mempengaruhi kompetensi yang dimiliki dosen. Hasil penelitian juga menjelaskan 
bahwa kompetensi guru dalam memberikan pengajaran berpengaruh terhadap $e$ learning yang diajarkan. Hasil penelitian Amanahtuzuriah dkk. (2017) menjelaskan bahwa semakin baik kompetensi yang dimiliki guru akan memberikan dampak terhadap pembelajaran e-learning yang diberikan ketika kelas online. Penelitian ini dilakukan untuk mengidentifikasi motivasi belajar dan pengembangan kompetensi berbasis e-development yaitu pembelajaran e-learning pada mahasiswa untuk memenuhi kebutuhan industri kerja.

\section{Pengaruh Motivasi Belajar terhadap Kompetensi}

Dorongan eksternal dan internal pada orang yang sedang belajar untuk mengadakan tingkah laku dengan disertai unsur-unsur yang mendukung adalah motivasi belajar. Unsur-unsur tersebut berupa adanya keinginan untuk berhasil, harapan dan citacita masa depan, kebutuhan untuk belajar, harapan dalam belajar, dan lingkungan belajar yang kondusif (Uno, 2011). Motivasi belajar adalah proses yang memberi semangat belajar, arah, dan kegigihan perilaku sehingga perilaku yang termotivasi adalah perilaku yang penuh energi, terarah dan tahan lama. Kompetensi sumber daya manusia merupakan sifat dasar yang melekat pada setiap individu pada dan perilaku yang dapat diprediksi pada berbagai keadaan dalam melaksanakan tugas pekerjaan untuk mempunyai prestasi dan keinginan berusaha agar dapat menjalankan tugas secara efektif. Prediksi individu yang dapat bekerja dengan baik dan kurang baik dapat diukur dari kriteria yang ditetapkan. Individu yang memiliki ketidaksesuaian kompetensi inilah yang membedakan individu unggul dari individu dengan prestasi terbatas.

Menurut Ihsanti (2014) individu dengan kompetensi istimewa dan kompetensi terbatas merupakan suatu pedoman untuk pekerjaan tertentu dalam pemilihan karyawan (personal selection), penilaian kerja (performance appraisal), perencanaan pengalihan tugas (succession planning), dan pengembangan (development). De Vos dkk. (2011) mendefinisikan pengembangan kompetensi sebagai ciri-ciri yang penting dalam manajemen kompetensi yang mencakup semua kegiatan yang dibawa oleh organisasi dan pegawai untuk memelihara atau meningkatkan fungsional pegawai, pembelajaran dan kompetensi karir. Hasil penelitian Satria \& Kuswara (2013) menjelaskan hubungan antara motivasi belajar terhadap kompetensi dosen yang mengajar kepada mahasiswa berpengaruh positif dan signifikan. Maka, hipotesis pada penelitian ini yaitu:

$\mathrm{H}_{1}$ : Pengaruh motivasi belajar terhadap kompetensi

\section{Pengaruh Motivasi Belajar terhadap Metode e-Learning}

Dorongan yang ada dalam diri siswa dalam hal ini adalah indikator motivasi belajar akan menyertai siswa tersebut dari awal kegiatan belajarnya sampai siswa tersebut merasa cukup untuk mencapai tujuan belajarnya. Menurut Khan (2005), elearning menunjuk pengiriman materi pembelajaran kepada siapapun, dimanapun, dan kapanpun. Penggunaan e-learning di berbagai teknologi menciptakan lingkungan belajar yang lebih terbuka, fleksibel, dan terdistribusi.

E-learning juga dapat dilihat sebagai proses pembelajaran yang efektif dan dapat menghasilkan penggabungan dalam penyampaian materi secara digital yang terdiri dari dukungan dan layanan dalam belajar (Waller \& Wilson, 2001). Menurut hasil penelitian Hasan \& Bao (2020), menjelaskan bahwa motivasi adalah niat mahasiswa untuk mengikuti perkuliahan secara daring dan mampu memengaruhi pembelajaran secara daring menggunakan e-learning. Maka, hipotesis pada penelitian ini yaitu:

$\mathrm{H}_{2}$ : Pengaruh motivasi belajar terhadap metode e-learning 


\section{Pengaruh Kompetensi terhadap Metode e-Learning}

Beberapa penelitian telah menunjukkan bahwa pengembangan kompetensi melalui $e$-learning dapat diidentifikasi. Inisiatif $e$ learning bertujuan mengembangkan kompetensi tenaga kerja yang dilakukan dengan membangun hubungan antara kompetensi dan tugas sebagai proses sebuah pembelajaran (Ley dkk., 2005). Dalam artikel yang ditulis oleh Ehlers dkk. (2008) disebutkan bahwa e-learning merupakan sebuah tantangan untuk pengembangan kompetensi. Dalam penjelasan ini, pendidikan tinggi e-learning kolaboratif berpotensi menstimulus pengembangan kompetensi.

Selanjutnya Ehlers dkk. (2008) membuktikan bahwa e-learning dapat meningkatkan jenjang dan menunjukkan peran sendiri dalam pengembangan kompetensi dan perubahan secara menyeluruh. E-learning menjadi salah satu sarana pembelajaran yang dapat membantu mahasiswa untuk lebih termotivasi dalam mengaktualisasikan materi pelatihan pengembangan kompetensi yang disajikan pada saat on campus. Kebutuhan pengembangan kompetensi mahasiswa diiringi dengan perkembangan kemajuan teknologi di bidang pendidikan dan pelatihan. Hal ini dapat ditunjang melalui $e$ learning sebagai model pembelajaran dan pelatihan pengembangan kompetensi bersertifikat.

Holmes \& Gardner (2006) menyimpulkan bahwa penggunaan $e$ learning dapat meningkatkan motivasi dan hasil tugas serta memberikan ruang bagi peserta didik yang memiliki potensi untuk mengeksplorasi diri dengan maksimal. Hasil penelitian Khayatun \& Retnaningdyastuti (2017) menjelaskan kompetensi menjadi dasar bagi pengajar untuk memahami bagaimana terhadap elearning yang dipelajari oleh mahasiswa. Maka, hipotesis pada penelitian ini yaitu:

$\mathrm{H}_{3}$ : Pengaruh kompetensi terhadap metode e-learning

\section{METODE PENELITIAN}

Penelitian dilakukan di Politeknik Negeri Jakarta, Kota Depok dengan subjek penelitian adalah mahasiswa jurusan Administrasi Niaga. Penelitian ini menggunakan pendekatan kuantitatif dengan metode explanatory research. Explanatory research merupakan metode yang menjelaskan suatu pengaruh variabel dengan variabel lainnya menggunakan statistik inferensial (Prasetyo \& Jannah, 2012). Statistik inferensial digunakan untuk menganalisis data sampel dan hasilnya akan digeneralisasi untuk populasi dimana sampel diambil.

Tabel 1. Karakteristik Responden

\begin{tabular}{lcc}
\hline Katagori & Frekuensi & Persentase \\
\hline Jenis Kelamin & & \\
Laki-Laki & 15 & $15 \%$ \\
Perempuan & 85 & $85 \%$ \\
Katagori Umur & & \\
18 Tahun & 6 & $6 \%$ \\
19 Tahun & 43 & $43 \%$ \\
20 Tahun & 31 & $31 \%$ \\
21 Tahun & 18 & $18 \%$ \\
22 Tahun & 1 & $1 \%$ \\
23 Tahun & 1 & $1 \%$ \\
Program Studi & & \\
Administrasi & 35 & $35 \%$ \\
Bisnis (D3) & & \\
Administrasi & 47 & $47 \%$ \\
Bisnis Terapan & & \\
(D4) & & \\
MICE (D4) & 18 & $18 \%$ \\
Tahun Masuk & & \\
2017 & 16 & $16 \%$ \\
2018 & 42 & $42 \%$ \\
2019 & 42 & $42 \%$ \\
\hline
\end{tabular}

Populasi dalam penelitian ini adalah mahasiswa jurusan administrasi bisnis sebanyak 1094 mahasiswa dengan pengambilan teknik sampel dalam penelitian ini menggunakan random sampling. Responden yang diambil dalam penelitian ini adalah mahasiswa aktif Jurusan Administrasi Niaga Politeknik Negeri Jakarta, Provinsi DKI Jakarta. Jumlah responden dalam penelitian ini sebanyak 100 mahasiswa dengan perbedaan latar belakang jenis kelamin, umur, program studi, dan tahun masuk. Responden memberikan penilaian berbeda 
tentang pengaruh kompetensi dan motivasi belajar terhadap penggunaan e-learning di jurusan Administasi Niaga Politeknik Negeri Jakarta. Identitas responden dijelaskan pada Tabel 1.

Berdasarkan data Tabel 1 yang diperoleh dari 100 responden, 15\% diantaranya berjenis kelamin laki-laki dan $85 \%$ berjenis kelamin perempuan. Hal ini menunjukkan bahwa mayoritas yang mengisi kuesioner adalah berjenis kelamin perempuan. Melalui Tabel 1 diketahui bahwa responden terbanyak terdapat pada katagori usia 19 tahun yaitu sebesar $43 \%$ dari seluruh responden. Dari data tersebut dapat diketahui bahwa sebagian besar mahasiswa yang mengisi kuesioner. Sebesar $47 \%$ responden diantaranya berasal dari program studi Administrasi Binis Terapan (D4), 35\% dari program studi Administasi bisnis (D3), dan 18\% berasal dari program studi MICE (D4). Selain itu, persentase responden yang mengisi kuesioner sebanyak $42 \%$ yang masuk tahun 2018 dan 2019, serta 16 orang atau sebesar $16 \%$ responden yang yang masuk ke jurusan Administrasi Niaga pada tahun 2017.

\section{HASIL DAN PEMBAHASAN}

Validitas konstruk digunakan untuk mengetahui sampai seberapa jauh indikator mampu merefleksikan konstruk laten teoritis. Validitas konstruk menjelaskan ukuran indikator yang diambil dari sampel untuk menggambarkan skor sesungguhnya di dalam populasi. Pengukuran dilakukan melalui uji validitas yang digunakan yaitu convergent validity, variance extracted, construct reliability, dan discriminant validity.

Syarat yang harus dipenuhi digambarkan standardized estimate yang harus lebih dari 0,50 dan idealnya harus 0.70 agar loading factor signifikan. Berikut adalah tabel standardized loading estimate.

Tabel 2 menunjukkan bahwa indikator KD6 dan EL4 memiliki nilai faktor loading dibawah 0,50 sehingga indikator tersebut tidak layak untuk digunakan dalam penelitian. Berikut disajikan tabel dibawah yaitu faktor loading (convergent validity yang valid), AVE, construct reliability, dan discriminant validity.

Tabel 2. Standart Loading Tabel Estimate

\begin{tabular}{lccc}
\hline & $\begin{array}{c}\text { Loading Factor } \\
\text { Motivasi } \\
\text { Belajar }\end{array}$ & $\begin{array}{c}\text { Kompetensi } \\
\text { Dosen }\end{array}$ & $\begin{array}{c}\text { E- } \\
\text { Learning }\end{array}$ \\
\hline MB1 & 0,776 & & \\
MB2 & 0,618 & & \\
MB3 & 0,738 & & \\
MB4 & 0,677 & & \\
MB5 & 0,701 & & \\
MB6 & 0,494 & & \\
KD1 & & 0,630 & \\
KD2 & & 0,678 & \\
KD3 & & 0,669 & \\
KD4 & & 0,672 & \\
KD5 & & 0,647 & 0,630 \\
KD6 & & 0,488 & 0,717 \\
EL1 & & & 0,760 \\
EL2 & & & 0,266 \\
EL3 & & & 0,731 \\
EL4 & & & 0,854 \\
EL5 & & & bahwa \\
EL6 & & & \\
\hline & & & \\
Tabel 3 & menunjukkan & \\
\hline
\end{tabular}

keseluruhan nilai factor loading pada setiap indikator telah memenuhi kriteria yaitu di atas 0.50. Variance extracted digunakan untuk melihat jumlah varians dari indikatorindikator yang diekstraksi oleh variabel bentukan yang dikembangkan. Nilai variance extracted yang tinggi menunjukkan bahwa indikator-indikator itu telah mewakili variabel bentukan yang dikembangkan. Berdasarkan Tabel 3 menunjukkan bahwa hasil variance extracted semua konstruk mempunyai nilai AVE yang baik karena telah memenuhi syarat cut-off value yaitu sama dengan atau di atas 0.50 .

Salah satu indikator convergent validity adalah reliabilitas. Penggunaan croncbach alpha sebagai ukuran reliabilitas juga cukup banyak digunakan, walaupun kenyataannya croncbach alpha memberikan reliabilitas yang lebih rendah. Berdasarkan Tabel 3 dapat diketahui bahwa nilai composite reliability pada masingmasing variabel adalah $>0.5$ serta nilai croncbach alpha pada masing-masing 
variabel adalah $<0,7$. Menurut hasil Tabel 3, dapat disimpulkan bahwa data yang digunakan dalam penelitian reliabel.

Discriminant validity adalah uji yang dilakukan guna melihat konstruk variabel valid atau tidak. Berikut merupakan hasil output korelasi antar konstruk variabel yang tersaji pada Tabel 4.

Tabel 3. Covergent Validity, Construct Reliability, AVE, Cronbachs Alpha

\begin{tabular}{lccccc}
\hline & Item & $\begin{array}{c}\text { Convergent } \\
\text { Validity }\end{array}$ & $\begin{array}{c}\text { Construct } \\
\text { Reliability }\end{array}$ & AVE & $\begin{array}{c}\text { Cronbachs } \\
\text { Alpha }\end{array}$ \\
\hline Motivasi Belajar & MB1 & 0,776 & 0,830 & 0,596 & 0,748 \\
& MB2 & 0,618 & & & \\
& MB3 & 0,738 & & & \\
& MB4 & 0,677 & & & \\
Kompetensi Dosen & MB5 & 0,701 & & & \\
& KD1 & 0,623 & 0,827 & 0,596 & \\
& KD2 & 0,757 & & & \\
& KD3 & 0,727 & & & \\
& KD4 & 0,725 & & & \\
& KD5 & 0,656 & & & \\
& EL1 & 0,642 & 0,861 & & \\
& EL2 & 0,722 & & & \\
& EL3 & 0,768 & & & \\
& EL5 & 0,722 & & & \\
& EL6 & 0,853 & & & \\
& & & & & \\
& & & & & \\
\end{tabular}

Tabel 4. Discriminant Validity

\begin{tabular}{lccc}
\hline & $(1)$ & $(2)$ & $(3)$ \\
\hline (1) Motivasi & 0,704 & & \\
Belajar & & & \\
(2) Kompetensi & & 0,699 & \\
Dosen & & & \\
(3) e-Learning & & & 0,745 \\
\hline
\end{tabular}

Berdasarkan Tabel 4 diketahui bahwa nilai descriminant validity $>0,6$ sehingga konstruk variabel keseluruhannya adalah valid.

\section{Hasil Pengujian Hipotesis}

Berdasarkan Gambar 1 diketahui bahwa nilai koefisien tertinggi variabel motivasi belajar adalah MB1 sebesar 0.776 yang menunjukkan untuk MB1 korelasi terkuat diantara indikator lainnya, nilai terendah yaitu pada MB2 sebesar 0.618. Variabel kompetensi dosen tertinggi adalah KD2 sebesar 0.757 yang menunjukkan korelasi terkuat diantara indikator lainnya. Nilai terendah yaitu pada KD1 sebesar 0.623. Variabel E-Learning EL6 yang memiliki nilai tertinggi sebesar 0.853 yang menunjukkan untuk EL6 korelasi terkuat diantara indikator lainnya, nilai terendah yaitu pada EL1 sebesar 0.642.

Berdasarkan Gambar 2 diketahui hasil bootstraping dengan nilai tertinggi adalah motivasi belajar terhadap kompetensi dosen dibandingkan e-learning. Motivasi belajar dibandingkan kompetensi dosen memiliki nilai tertinggi yang memengaruhi $e$ learning. Hasil yang dipengaruhi bernilai positif sehingga menunjukkan pengaruh positif secara menyeluruh. Untuk hasil pengujian hipotesis, peneliti menggunakan data PLS-SEM dan memperoleh hasil pada Tabel 5. 


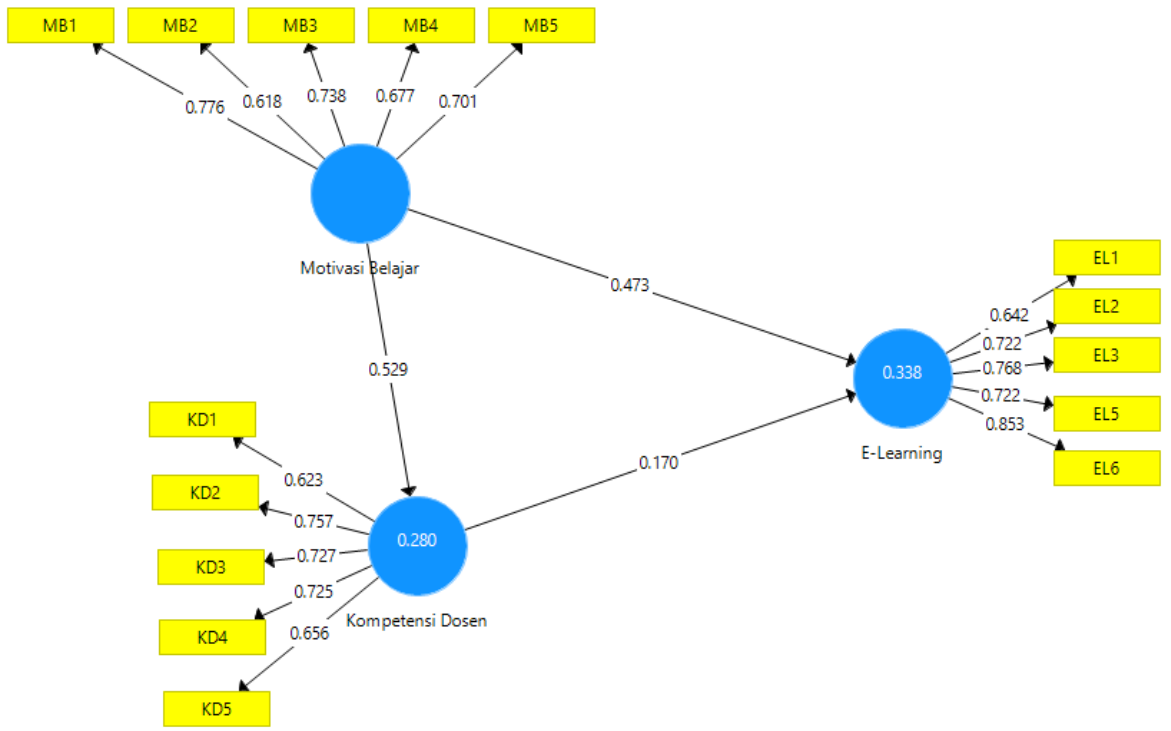

Gambar 1. Hasil PLS-SEM Alogaritma

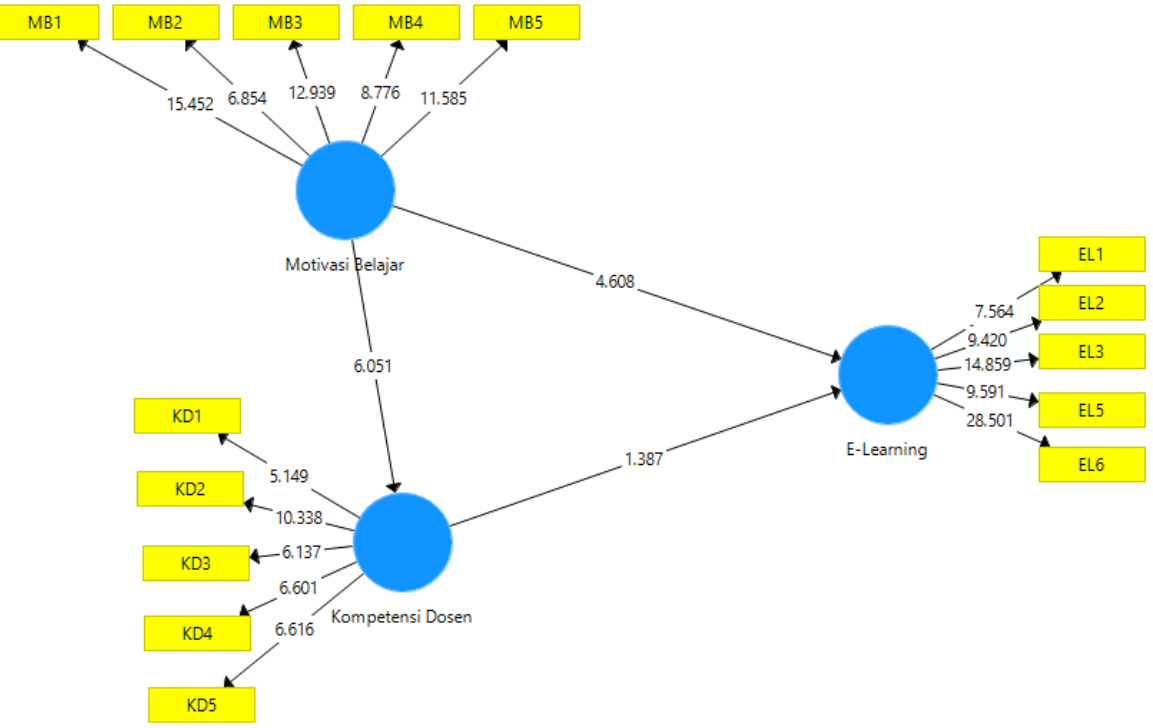

Gambar 2. Hasil Bootstraping

Tabel 5. Path Coefficients (Mean, STDEV, T-Values)

\begin{tabular}{lccccc}
\hline & $\begin{array}{c}\text { Original } \\
\text { Sample }(\mathbf{O})\end{array}$ & $\begin{array}{c}\text { Sample } \\
\text { Mean }(\mathbf{M})\end{array}$ & $\begin{array}{c}\text { Standard } \\
\text { Deviation } \\
\text { (STDEV) }\end{array}$ & $\begin{array}{c}\text { T Statistics } \\
(\mid \mathbf{O} \text { STDEV })\end{array}$ & P Values \\
\hline $\mathbf{M B ~} \rightarrow$ KD & 0,691 & 0,681 & 0,076 & 9,131 & 0,001 \\
$\mathbf{M B} \rightarrow$ EL & 0,317 & 0,290 & 0,117 & 1,990 & 0,000 \\
$\mathbf{K D} \rightarrow$ EL & 0,030 & 0,022 & 0,135 & 2,221 & 0,002 \\
\hline
\end{tabular}

Tabel 6. Hasil Rangkuman Hipotesis

\begin{tabular}{lcc}
\hline \multicolumn{1}{c}{ Hipotesis } & $\boldsymbol{p}$ Values & Keterangan \\
\hline H1: Ada pengaruh antara motivasi belajar terhadap kompetensi & 0.001 & Diterima \\
H2: Ada pengaruh antara motivasi belajar terhadap e-learning & 0.000 & Diterima \\
H3: Ada pengaruh antara kompetensi dosen terhadap e-learning & 0.002 & Diterima \\
\hline
\end{tabular}




\section{Pengaruh Motivasi Belajar terhadap Kompetensi}

Berdasarkan hasil uji hipotesis pertama diketahui bahwa nilai signifikansi $\mathrm{t}$ diperoleh sebesar $0,000<0,001$, hal ini membuktikan bahwa hipotesis pertama diterima dengan nilai t statistik sebesar 9.131 > t tabel (1.96). Hasil tersebut menjelaskan bahwa terdapat pengaruh positif dan signifikan antara motivasi belajar terhadap kompetensi. hasil ini membuktikan bahwa belajar yang termotivasi adalah perilaku yang penuh energi, terarah dan tahan lama.

Kompetensi sumber daya manusia yang dimiliki individu bersifat dasar atau merupakan bagian kepribadian yang melekat dan dapat diprediksi pada berbagai keadaan dalam melaksanakan tugas pekerjaan untuk mempunyai prestasi dan keinginan berusaha agar dapat menjalankan tugas secara efektif. Prediksi individu yang dapat bekerja dengan baik dan kurang baik dapat diukur dari kriteria yang ditetapkan. Individu yang memiliki ketidaksesuaian kompetensi inilah yang membedakan individu unggul dari individu dengan prestasi terbatas.

Hasil penelitian ini membuktikan secara empiris bahwa terdapat motivasi belajar terhadap kompetensi. Hasil penelitian ini didukung dan konsisten dengan hasil penelitian terdahulu yang dilakukan Satria \& Kuswara (2013) menyatakan bahwa adanya pengaruh motivasi belajar terhadap kompetensi.

\section{Pengaruh Motivasi Belajar terhadap E- Learning}

Berdasarkan hasil uji hipotesis kedua diketahui bahwa nilai signifikansi $\mathrm{t}$ diperoleh sebesar $0,000<0,000$, yang membuktikan bahwa hipotesis kedua diterima dengan nilai $\mathrm{t}$ statistik sebesar $1.990>t$ tabel (1.96). Hasil ini menjelaskan bahwa terdapat pengaruh positif dan signifikan antara motivasi belajar terhadap e-learning.

Dorongan yang ada dalam diri siswa ini akan menyertai siswa tersebut dari awal kegiatan belajarnya sampai siswa tersebut merasa cukup untuk mencapai tujuan belajarnya. Menurut Khan (2005), $e$ learning menunjuk pada pengiriman materi pembelajaran kepada siapapun, dimanapun, dan kapanpun dengan menggunakan berbagai teknologi dalam lingkungan pembelajaran yang terbuka, fleksibel, dan terdistribusi.

Hasil penelitian ini membuktikan secara empiris bahwa terdapat pengaruh antara motivasi belajar terhadap e-learning. Hasil penelitian ini mendukung atau konsisten dengan penelitian terdahulu yang dilakukan oleh Hasan \& Bao (2020), yang menyatakan bahwa motivasi belajar berperan sebagai niat mahasiswa untuk mengikuti perkuliahan secara daring mampu mempengaruhi pembelajaran secara daring menggunakan e-learning .

\section{Pengaruh Kompetensi terhadap E- \\ Learning}

Berdasarkan hasil uji hipotesis ketiga diketahui bahwa nilai signifikansi $t$ diperoleh sebesar $0,000<0,002$, yang membuktikan bahwa hipotesis ketiga diterima dengan nilai $\mathrm{t}$ statistik sebesar $2.221<\mathrm{t}$ tabel (1.973). Hasil tersebut menjelaskan bahwa terdapat pengaruh positif kompetensi terhadap e-learning berpengaruh secara signifikan.

Beberapa penelitian telah menunjukkan bahwa pengembangan kompetensi melalui e-learning dapat diidentifikasi. Ley dkk. (2005) mengatakan bahwa inisiatif e-learning ditujukan untuk pengembangan kompetensi tenaga kerja yang dilakukan dengan membangun hubungan antara kompetensi dan tugas juga mamandang pengembangan kompetensi sebagai proses sebuah pembelajaran.

Hasil penelitian ini membuktikan secara empiris bahwa terdapat pengaruh kompetensi terhadap e-learning secara positif dan signifikan. Hasil penelitian ini mendukung atau konsisten dengan penelitian terdahulu yang dilakukan oleh penelitian Khayatun \& Retnaningdyastuti (2017), yang menjelaskan kompetensi 
menjadi dasar bagi pengajar untuk memahami bagaimana e-learning yang dipelajari oleh mahasiswa.

\section{SIMPULAN DAN SARAN}

Berdasarkan hasil penelitian yang dilakukan pengaruh motivasi belajar dan kompetensi terhadap pembelajaran elearning pada mahasiswa Jurusan Administras Niaga sebagai berikut. Pertama, hasil penelitian yang dilakukan untuk mengetahui pengaruh motivasi belajar terhadap kompetensi terbukti berpengaruh positif dan signifikan $\left(\mathrm{H}_{1}\right.$ diterima). Motivasi belajar sebagai dorongan internal dan eksternal pada peserta didik yang sedang belajar untuk mengadakan perubahan perilaku mampu memberikan pengaruh terhadap kompetensi sebagai suatu karakteristik dasar dari seseorang yang memungkinkannya memberikan kinerja unggul dalam pekerjaan, peran, atau situasi tertentu.

Kedua, hasil penelitian yang dilakukan untuk mengetahui pengaruh motivasi belajar terhadap e-learning terbukti berpengaruh positif dan signifikan ( $\mathrm{H}_{2}$ diterima). Hal ini terjadi karena motivasi belajar secara lebih spesifik yang terwujud menjadi dua hal yaitu berupa dorongan internal maupun eksternal bagi mahasiswa yang sedang belajar untuk mengadakan perubahan tingkah laku. Pada umumnya, beberapa indikator yang mendukung pengaruh e-learning merupakan proses pembelajaran efektif yang dihasilkan melalui penggabungan penyampaian materi secara digital yaitu, dukungan dan layanan belajar.

Ketiga, hasil penelitian yang dilakukan untuk mengetahui pengaruh kompetensi terhadap e-learning terbukti berpengaruh positif dan signifikan $\left(\mathrm{H}_{3}\right.$ diterima). Hal ini dikarenakan pengembangan kompetensi penting dalam manajemen kompetensi yang mencakup semua kegiatan dibawah organisasi dan pegawai untuk memelihara dan meningkatkan fungsional pegawai. Dosen sebagai tenaga pendidik dapat memengaruhi mahasiswa melalui $e$ learning sebagai proses pembelajaran secara efektif yang dihasilkan dengan cara menggabungkan penyampaian materi secara digital.

\section{REFERENSI}

Amanahtuzuriah, A., Nurmadiah, N., \& Asmariani, A. (2017). Pengaruh Kepemimpinan Kepala Sekolah Terhadap Kompetensi Guru Di SDN 035 Tembilahan. Al-Afkar: Jurnal Keislaman \& Peradaban, $5(1)$.

De Vos, A., De Hauw, S., \& Willemse, I. (2011). Competency development in organizations: building an integrative model through a qualitative study. The Autonomus Management School of Ghent University and Katholieke Universiteit Leuven. 6482(1). 138.

Ehlers, U., Schneckenberg, D. \& Adelsberger, H. H. (2008). Stepping up the ladder competence development through e-learning? University of Duisburg Essen, Germany.

Firman, F., \& Rahayu, S. (2020). Pembelajaran online di tengah pandemi covid-19. Indonesian Journal of Educational Science (IJES), 2(2), 81-89.

Gikas, J., \& Grant, M. M. (2013). Mobile computing devices in higher education: Student perspectives on learning with cellphones, smartphones \& social media. Internet and Higher Education, 19(1), 18-26.

Hasan, N., \& Bao, Y. (2020). Impact of "eLearning crack-up" perception on psychological distress among college students during COVID-19 pandemic: A mediating role of "fear of academic year loss". Children and Youth Services Review, 118, 105355. 
Holmes, B., \& Gardner, J. (2006). Elearning: concepts and practice. London: SAGE Publications.

Ihsanti, E. (2014). Pengaruh kompetensi sumber daya manusia dan penerapan sistem akuntansi keuangan daerah terhadap kualitas laporan keuangan daerah (studi empiris pada SKPD kab. lima puluh kota). Jurnal Akuntansi, 2(3). 1163-1183.

Khan, B. (2005). Managing e-learning: Design, delivery, implementation and evaluation. Hershey: Information Science Publishing.

Khayatun, N., \& Retnaningdyastuti, R. (2017). Pengaruh Motivasi Kerja dan Diklat Terhadap Kompetensi Pedagogik Guru Sekolah Dasar di Kecamatan Sragi Kabupaten Pekalongan. Jurnal Manajemen Pendidikan (JMP), 6(1).

Ley, T., Lindstaedt, S., \& Albert, D. 2005. Competency development in knowledge management and elearning: supporting informal workplace learning. Lecture Notes in Artifial Inteligence, 3782, 189202.

Moore, J. L., Dickson-Deane, C., \& Galyen, K. (2011). e-Learning, online learning, and distance learning environments: Are they the same?. The Internet and higher education, 14(2), 129-135.
Prasetyo, B. \& Jannah. (2012). Metode penelitian kuantitatif. Jakarta: Rajawali Pers.

Rosenberg. (2001). E-learning: strategies for delivering knowledge in the digital age. New York: McGrawHill Education.

Sardiman. (2018). Interaksi dan motivasi belajar mengajar. Jakarta: Rajawali Press.

Satria, R. O., \& Kuswara, A. (2013). Pengaruh motivasi dan pelatihan terhadap kompetensi kerja serta implikasinya pada produktivitas pegawai Dinas Perhubungan Kota Bandung. Jurnal Ekonomi, Bisnis \& Entrepreneurship, 7(2).

Suwastika, I. W. K. (2018). Pengaruh elearning sebagai salah satu media pembelajaran berbasis teknologi informasi terhadap motivasi belajar mahasiswa. Jurnal Sistem dan Informatika (JSI), 13(1), 1-5.

Uno. (2011). Teori motivasi dan pengukurannya. Jakarta: Remaja Rosdaka Karya.

Waller, V., \& Wilson, J. (2001). A Definition for E-Learning" in Newsletter of Open and Distance Learning Quality Control. Tersedia: $\quad h t t p: / / w w w . o d l q c$. org.uk/odlqc, (19).

Zhang, D., Zhao, J. L., Zhou, L., \& Nunamaker Jr, J. F. (2004). Can elearning replace classroom learning?. Communications of the ACM, 47(5), 75-79. 